\title{
From elitist to popular tourism: leisure cruises to Spain during the first third of the twentieth century (1900-1936)
}

\author{
Gaetano Cerchiello* \\ gaetano.cerchiello@ua.es \\ José Fernando Vera-Rebollo* \\ jf.vera@ua.es \\ * University Institute for Tourism Research (University of Alicante) \\ Campus San Vicente del Raspeig \\ 03690 Alicante (Spain)
}

\begin{abstract}
:
This article analyses the evolution of ocean cruises in the first third of the twentieth century. It focuses on inbound cruise traffic to Spain as well as major outbound national markets, particularly the United Kingdom. Analysis is carried out using mainly archival and newspaper sources. The chronological structure of the paper highlights the important changes that took place throughout the period of study. Before the First World War, leisure cruises constituted a sporadic activity. During the inter-war period and particularly after the 1920s, the number of cruises offered grew exponentially. The paper reveals the high level of dependency that ocean cruises had on transatlantic shipping line services and migration traffic. It demonstrates that cruise activity evolved in a very different way to the tourism phenomenon in general. The diffuse and widespread idea that in the past cruses were an exclusive privilege of the elite classes is open to question. During the period between the two world wars, the socio-economic characteristics of cruise passengers changed significantly. Ocean cruises became a holiday product accessible to a much wider and heterogeneous market, particularly in Britain.
\end{abstract}

Keywords:

Tourism history, ocean cruises, maritime transport, socioeconomic changes, migration traffic 


\section{Introduction: objectives, methodology and structure}

This paper traces the evolution of cruise tourism during the first third of the twentieth century, one of the most important periods in cruise history. It was, in fact, in the first half of the 1930s, and not during the 1960s, when ocean cruises started to become an affordable and popular form of leisure travel. The present research covers both issuing and receiving dimensions. On the one hand, it addresses ocean cruises calling at Spanish ports, looking at inbound cruise traffic to Spain and its evolution throughout the period under study. On the other hand, the cruise products offered in some of the main national markets are examined, particularly the United Kingdom. To achieve this, we explore strategies adopted by the large transatlantic shipping companies and travel agencies. In all cases our study refers to ocean cruises and not coastal cruises. The two forms of so-called 'maritime tourism' reveal important differences in terms of concept and content. Also according to the World Tourism Organization Maritime, excursions should not be regarded as a 'reduced' version of cruises. The marked differences reside in the type of customer as well as the characteristics of the ships and the length of the journeys. Furthermore, the two practices emerged at different times. From the earliest initiatives in the first half of the nineteenth century, coastal cruises were a popular product. Short trips meant affordable prices, which gradually dropped as a consequence of technological innovations and subsequent reductions in operating costs. Ocean cruises, on the contrary, were first promoted at the end of the 19th century. They constituted an elite activity and could only be afforded by those with very high incomes and time availability.

In the following pages, readers will also find a wealth of information about transoceanic migration traffic. The reason is very simple. Although they constituted a recreational activity, ocean cruises emerged (and developed prior to the establishment of the modern industry in the 1960s) as a supplementary activity of the shipping business, and more precisely as a replacement market for the transport of migrants. In other words, the analysis of cruise activity should not only be considered within the context of economic, social, political and technological changes which favoured the development of tourism, but also in line with changes occurring in the maritime transport sector.

We carried out our enquiry mostly through the combined use of archival and newspaper sources, particularly promotional advertisements and port records of the entry and exit of ships. Following the methodology proposed by Derek M. Williams, ${ }^{1}$ advertising material provides a wealth of information about the supply of cruises: organising entity, dates, itinerary, stopovers, geographic market, unit of transport, etc. An example of this can be seen in Figure 1 which shows an advertisement for three cruises on board Arandora Star of the Blue Star Line. The first is a 30-

\footnotetext{
${ }^{1}$ Derek M. Williams, 'Market Pressures and Innovation: The Orient Steam Navigation Co. and the Development of Pleasure Cruising, 1888-1900', The Northern Mariner/Le Marin du Nord 10, no. 4 (2000): 1-12.
} 
day Mediterranean cruise departing from Southampton on 12 October 1935, with the first call in Barcelona. All of this starting from a minimum price per person of 55 guineas (about $£ 58$ ).

Figure 1. Advertisement for Blue Star Line cruises (1935-1936)

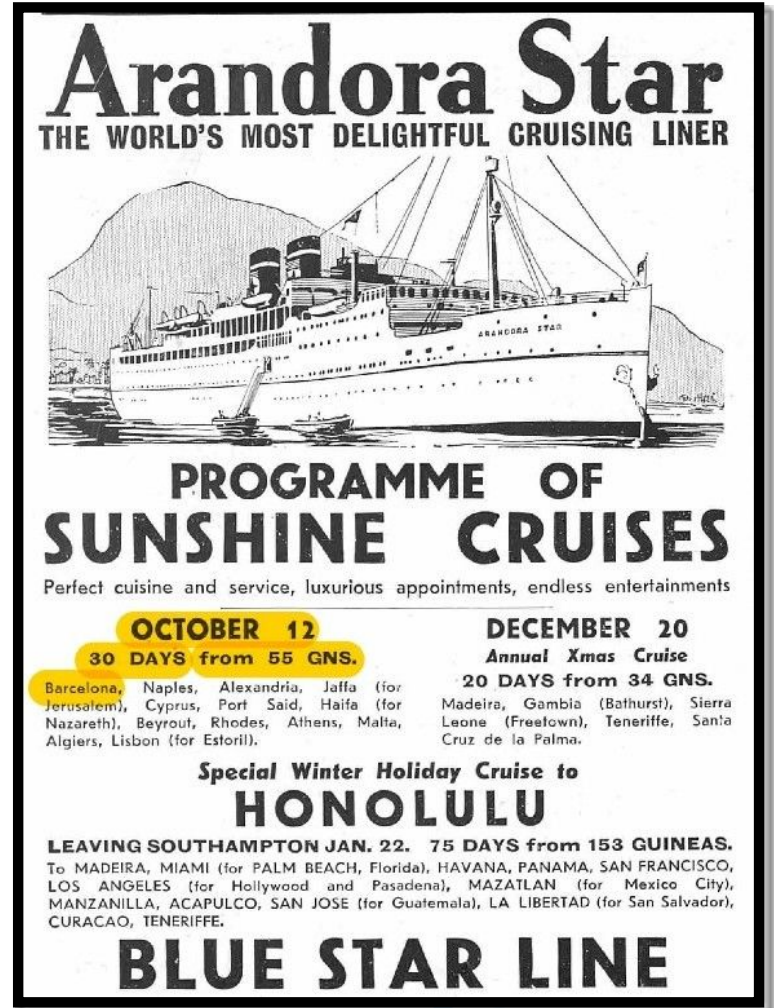

Source: The Sphere, 28 September 1935, 40

As well as corroborating information, records of ship entries and exits complement the use of advertisements, frequently indicating the number of passengers on specific boats. In other words, they reveal the response of the public. This valuable source can often be found in port archives, or, alternatively, in maritime chronicles printed by local papers. Many newspapers issued in port towns, both in Spain and abroad, reported local shipping activities on a daily basis. Figure 2, for example, reproduces two extracts from the La Vanguardia newspaper recounting Barcelona port traffic on 18 October 1935. The local newspaper noted that the day before, among other ships, the Arandora Star had arrived in the morning from Southampton with 161 passengers.. The 'cruising liner' left Barcelona late at night on the same day and continued its journey through other Mediterranean ports listed in the itinerary found in Figure 1 above.

Joint analysis of advertisements and port chronicles is essential for deepening our knowledge about the historical evolution of cruise traffic. In order to examine the British and US issuing markets, we used digital resources available through the British Newspaper Archive and the Library of Congress respectively. In the case of Italy, we utilised La Stampa's digital newspaper archive. In 
order to analyse traffic received by Spain, the Barcelona newspaper La Vanguardia was very helpful together with Biblioteca Nacional de España's (Spanish National Library) and Biblioteca Virtual de Prensa Histórica's (Virtual Library of Historical Newspapers) digital portals. All these applications provide search engines with highly effective filters that enable and facilitate the rapid collecting and downloading of data.

\section{Figure 2. Extracts of port chronicle of Barcelona on 18 October 1935}

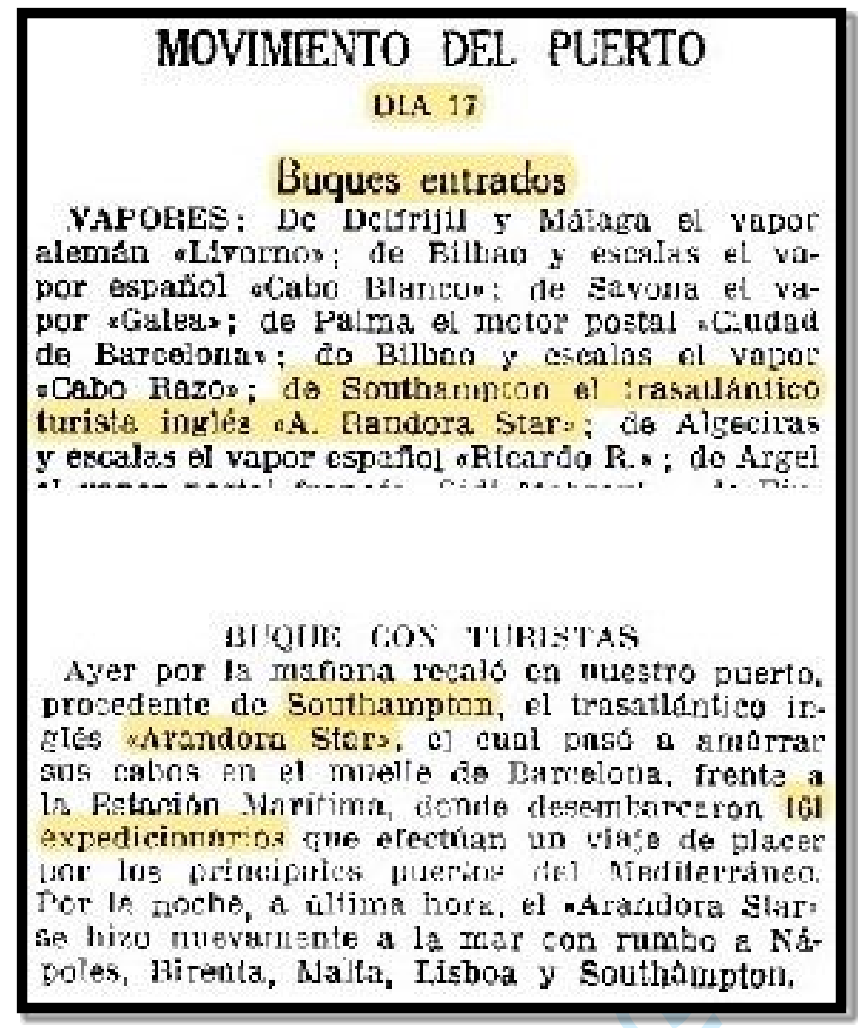

Source: La Vanguardia, 18 October 1935, 21

This study is structured chronologically and has four sections in addition to the introduction and the conclusion. After a brief overview of the origins of maritime tourism, we analyse the principal features of cruise activity during the years preceding the First World War. The third section examines the new business strategy adopted by shipping companies from the mid-1920s within the context of the long-distance maritime passenger transport crisis. The last section describes new developments in the mid-1930s and includes a quantitative estimate of cruise traffic in several Spanish ports.

\section{Origins of maritime tourism in the nineteenth century}


Maritime excursions date back to the end of the first quarter of the nineteenth century. After the introduction of steam navigation in the United Kingdom it did not take long for tourism developers to offer leisure trips operating from Southampton, Bristol, Glasgow, London, Liverpool and other coastal towns. ${ }^{2}$ The opportunity to plan the length of aquatic crossings for the first time, as opposed to the much less precise realities associated with weather-dependent sailing vessels, gave rise to the organisation of short journeys to nearby destinations. These initiatives had the purpose of providing transport to specific events (fairs, markets, inaugurations, etc.) or visiting emerging seaside resorts. Day-trips to the Isle of Wight, in the south of England, are an example. Entrepreneurs promoted pleasure tours around this island from the beginning of the 1820s. They departed from the neighbouring ports of Southampton and Portsmouth during the summer season. According to advertisements in local newspapers, the Ariadne steamboat usually offered this recreational service from Southampton for 7 shillings per person, leaving at nine o'clock in the morning and returning at seven in the evening. ${ }^{3}$ The emergence of steamboats was "decisive" with respect to the development of popular and domestic tourism in Great Britain, 'anticipating the role of the railways'. ${ }^{4}$

Over the following decades, maritime excursions became more widespread in the Mediterranean, where steamboat offerings developed several years after the United Kingdom. ${ }^{5}$ Port chronicles recount a special trip aboard the Languedoc in August 1848. French steamboat operators organised a trip for 127 passengers from Algiers to Palma de Mallorca, with the 'sole' purpose of 'spending a few days at leisure' on the Balearic island. ${ }^{6}$ In September 1860, the Mahonés steamboat sailed from Barcelona to Mahón so that its passengers could get a close look at the king and queen of Spain while they spent their holidays on the island of Menorca. ${ }^{7}$

While coastal excursions were a direct and immediate consequence of the emergence of motor vessels, shipping companies began to promote ocean cruises at the end of the nineteenth century. ${ }^{8}$ Within a context of strong expansion in passenger traffic, some transatlantic companies began to

\footnotetext{
2 John Armstrong and Derek M. Williams: 'The steamboat and popular tourism', Journal of Transport History 26, no 1 (2005): 61-77.

${ }^{3}$ Hampshire Chronicle, 29 August 1825, 2.

${ }^{4}$ John K. Walton, 'La invención del turismo popular: Gran Bretaña, s. XVIII y XIX', Anuario IEHS 27, no. 1 (2012): 422; Derek M. Williams, "Humankind and the Sea: The Changing Relationship since the Mid-Eighteenth Century", International Journal of Maritime History 22 (2010): 1-14; John K. Walton, 'Tourism and maritime history', International Journal of Maritime History 26 (2014): 111.

5 Alain Servantie, 'Development of steamship travelling in Mediterranean (1833-1860)' in Seapower, Technology and Trade, eds. Dejanirah Couto, Feza Gunergun and María P. Pedani, (Istambul: Piri Reis University, 2014), 505; José M. Valdaliso, Los navieros vascos y la marina mercante en España, 1860-1935. Una historia económica (Bilbao: Instituto Vasco de Administración Pública 1991), 64-65.

${ }^{6}$ Gaetano Cerchiello and José Fernando Vera-Rebollo, 'Steamboats and pleasure travels: success and failure of the first Spanish initiatives in the mid-nineteenth century', Journal of Tourism History 7, no. 1-2 (2015): 18-35.

${ }^{7}$ La Corona, 6 September 1860.

${ }^{8}$ Derek M. Williams, 'The Extent of Transport Services Integration: SS Ceylon and the First 'Round the World' Cruise, 1881-1882', International Journal of Maritime History 15, no. 2 (2003), 135-146. Gaetano Cerchiello, 'Turismo de eventos: los cruceros españoles en la inauguración del canal de Suez de 1869', Cuadernos de Turismo 35 (2015), 95115.
} 
show interest in the tourism market. Their objective was to occupy the periods of low activity along shipping lines and to address the issue of excess transport capacity of their respective fleets. Therefore, cruises developed as a 'replacement product' for long-haul passenger services. ${ }^{9}$ An analysis of advertisements and press reviews reveals that, for example, trips aimed at elite North Americans operated between November and March, the low season of the North Atlantic route. New York newspapers are particularly revealing in this respect. In November 1898, the New York Tribune published one of the first reports addressing cruise activity in the United States. The lengthy article provided extensive information about the organisation of a voyage to the Mediterranean, operated by Hapag (Hamburg America Line), a 'powerful' German shipping company that competed with the large British companies Cunard and White Star Line for North Atlantic passenger transport. ${ }^{10}$ Departing from New York on 26 January 1899, the Winter Cruise to the Orient on board the transatlantic liner Augusta Victoria, called at Madeira, Gibraltar, Algiers, Villefranche, Syracuse, Malta, Alexandria, Jaffa, Izmir, Istanbul, Athens, Palermo, Naples and Genoa, before returning to New York after a 70-day trip. The New York newspaper particularly celebrated the decision of the German company to finally cater for the North American elite market, following the example that it had initiated in Europe a few years earlier.

The Orient Line (Orient Steam Navigation Co.) was another pioneering company in Europe. Created in 1878 to provide a service between the United Kingdom and Australia, the English company carried out its first tourist projects during its lowest period of activity, between March and September. ${ }^{11}$ Press reviews reported that one of its steamboats, the Garronne, passed through the port of Cadiz at the beginning of March 1891, with 94 'wealthy' English tourists on board, as part of the 50-day leisure cruise programme. ${ }^{12}$ Orient Line's cruise activity increased considerably during the last decade of the nineteenth century due to a serious crisis affecting services with Australia. The organisation of many leisure cruises in the Mediterranean and even around the Caribbean islands compensated the reduction in the number and frequency of line operations. The British company operated a total of 10 cruises in 1893, including some summer trips around the Norwegian fiords and the North Cape. The tourism programme ran for nearly all twelve months of the year. The steamboat Garonne began operating on 22 February 1893, departing from London and heading non-stop for Spain to undertake a Mediterranean cruise. It finished on 26 January 1894 when it arrived in London after a 66-day trip around the Caribbean and the Canary Islands. ${ }^{13}$

\footnotetext{
${ }^{9}$ Roger Cartwright and Clive Harvey, Cruise Britannia. The story of the British cruise ship (Brimscombe: Tempus, 2004), 11-14.

10 "A Winter cruise to the Orient", The New York Tribune, 6 November 1898, 17.

${ }^{11}$ Williams, 'Market Pressures and Innovation', 2.

12 The Bucks Herald, 21 February 1891, 4; La Libertad, 12 March 1891, 3; El Bien Público, 9 March 1891, 3.

${ }^{13}$ Williams, 'Market Pressures and Innovation', 6; The Cheltenham Looker-On, 14 October 1893, 954.
} 
Orient's cruise activity, however, was an isolated case. Furthermore, its share of the tourism market fell significantly at the end of the 1890s, as traffic between the United Kingdom and Australia began to climb back to pre-crisis levels. In general terms, cruises were relatively scarce during this period, particularly if we compare them to excursion traffic. At least until the 1920s, as we shall see in the next section, the leisure cruise was an occasional phenomenon and, in any event, depended on the viability of transatlantic line services.

\section{Elite cruises at the dawn of the First World War}

At the beginning of the twentieth century, transoceanic passenger transport experienced a period of 'prodigious' expansion. Vessels packed with European emigrants left on a daily basis, mostly heading for America, from both Mediterranean ports and from Northern Europe. ${ }^{14}$ The evolution of the Italian emigration flow represents one of the best examples of this process (Figure 3).

\section{Figure 3. Evolution of Italian transoceanic migration}

\section{Thousands of migrations (1881-1939)}

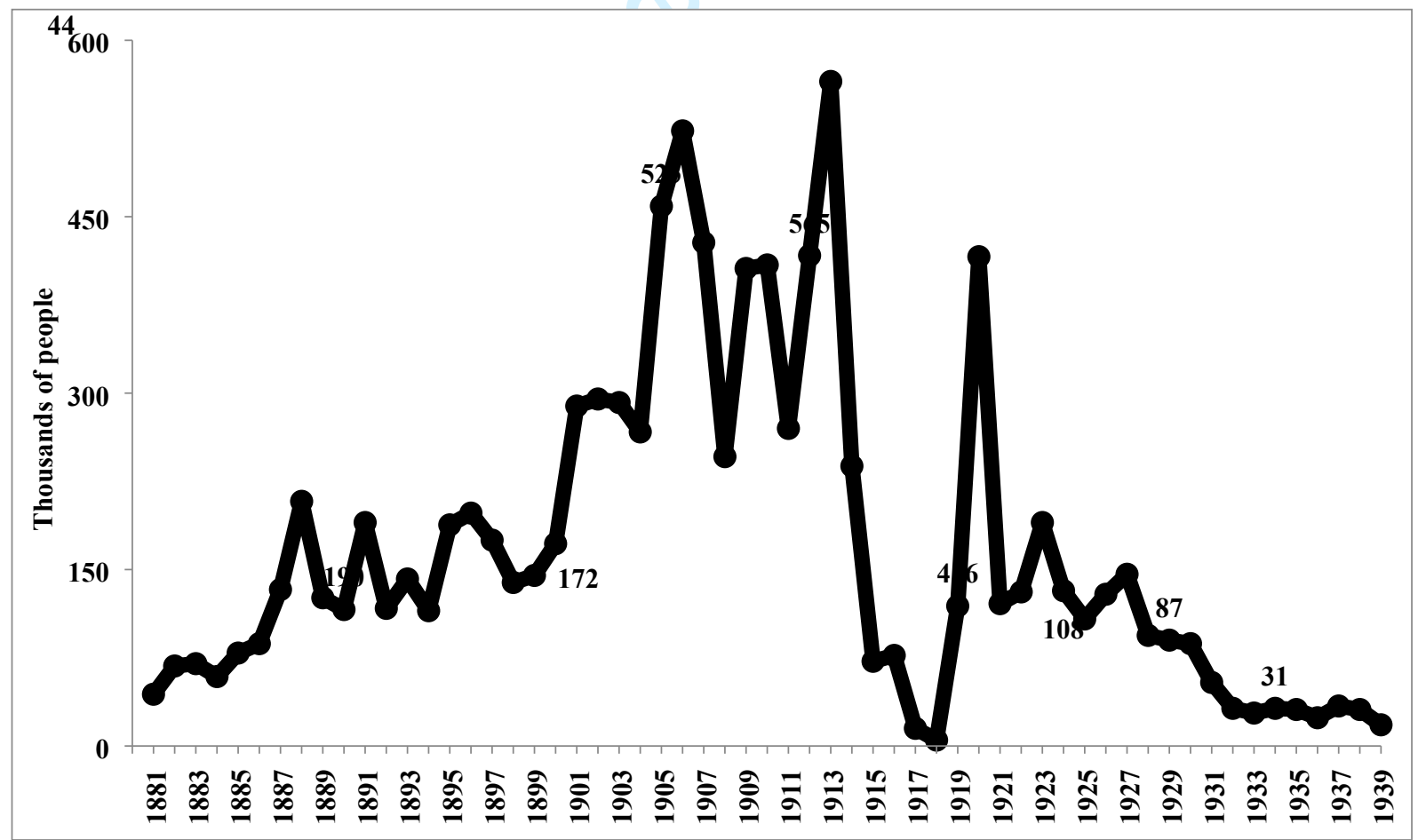

Source: Istituto Nazionale di Statistica, L'Italia in 150 anni. Sommario di statistiche storiche 1861-2010 (Rome: ISTAT, 2011).

\footnotetext{
14 Torsten Feys, The Battle for the Migrants: The introduction of steamshipping on the North Atlantic and its impact on the European exodus, (St. John's Newfoundland: International Maritime Economic History Association, 2013); Drew Keeling, The Business of Transatlantic Migration between Europe and the United States 1900-1914, (Zurich: Chronos, 2012); Walter Nugent, Crossings: the great transatlantic migration 1870-1914, (Bloomington: Indiana University, 1995).
} 
These figures, detailing one of the main emigrant source countries of the time, are highly revealing. It is estimated that more than seven and a half million Italians emigrated to a transoceanic destination between the beginning of the 1880s and 1914, travelling in third class or equivalent accommodation on merchant vessels. The greatest flows occurred from the turn of the century, with an annual average of over 350 thousand emigrants. By contrast, during the 1880 s, the number was usually less than 100 thousand passengers. With respect to European emigration as a whole, between 1901 and 1914, it is estimated that more than 11,700,000 people migrated to the United States, that is, more than $30 \%$ of all immigrants (European and other) who made the trip during the last two decades of the nineteenth century. ${ }^{15}$

The extraordinary passenger demand inspired significant changes in the shipping sector. Passenger transport became a core business. The prospect of large profits generated new investments and, in turn, modernisation and expansion of the fleets. Tonnage in the steam-powered merchant shipping sector increased considerably during the period leading up to the First World War. It is estimated that world growth between 1880 and 1914 exceeded $370 \% .{ }^{16}$ A series of technological developments such as the triple expansion engine, the widespread use of steel as a construction material and application of the steam turbine for propulsion fostered the construction of larger, faster and more efficient ships. ${ }^{17}$ Unlike in the past, the new vessels were specifically designed for the transport of passengers. ${ }^{18}$ The desire to gain control over migration flows between Europe and America generated a 'tariff war' among the large transatlantic companies which further stimulated demand for leisure voyages. ${ }^{19}$ Within this context, shipping companies were fully committed to line services while cruises took a back seat; there was no need to rely on alternative revenue streams because the companies' primary activity was running smoothly. Consequently, tourism initiatives during the early years of the twentieth century were sporadic, offered primarily during low periods of activity for liner services.

From an organisational point of view, the accommodation capacity of transatlantic ships was restricted to one class of service during cruises. The number of places on board dropped significantly, varying in accordance with ship size. The purpose of this measure was to avoid crowds of people and to offer better quality service to their ultra-elite clientele. According to a promotional announcement for a Mediterranean cruise on board the Moltke, leaving New York on

\footnotetext{
${ }^{15}$ U.S. Department of Labor, Annual Report of the Commissioner General of Immigration: 1911-1914.

${ }^{16}$ Instituto Nacional de Estadística, L'Italia in 150 anni.

17 Vaclav Smil, Prime Movers of Globalization: The History and Impact of Diesel Engines and Gas Turbines, (Cambridge Massachusetts: The MIT Press, 2010), 12-18.

${ }^{18}$ Daniel R. Headrick, The Tentacles of Progress. Technology Transfer in the Age of Imperialism 1850-1940, (Oxford: Oxford University, 1998); José M. Valdaliso, 'La transición de la vela al vapor en la flota mercante española: cambio técnico y estrategia empresarial', Revista de Historia Económica 10, no 1 (1992): 63-98.

${ }^{19}$ Feys, The Battle for the Migrants; Keeling, The Business of Transatlantic Migration.
} 
30 January 1905, the company, Hapag, informed readers that the maximum number of passengers was limited to 350 'although [the] steamer's full capacity' was 'over 600 in cabin'. This 'limitation' was considered 'absolutely necessary, so that landing and side trip facilities' were not 'overtaxed'. ${ }^{20}$

The low level of cruise traffic throughout the first quarter of the twentieth century is much more visible when analysing the Spanish case. In fact, records do not show any departures from Spanish ports during this period. All efforts made to organise such initiatives failed due to a shortage of clients, mechanical issues, or other operational reasons. ${ }^{21}$ Spanish shipping companies showed very little interest in leisure travel if it was not short in length. In terms of host destinations, the Spanish islands of Tenerife and Gran Canaria benefited almost exclusively from cruises originating in Northern Europe and were evidently excluded from the North American market. During their trips, English, French and German 'pleasure' vessels often stopped at the intermediate Spanish ports of Galicia (Vigo, La Coruña or even Villagarcía de Arosa), following the route established by transatlantic line services. The steamboat Orontes passed through the port of Vigo at least twice in the first decade of the century, specifically 1 June 1904 and 15 April 1907. In the first case, the ship, owned by Orient Line, carried 334 passengers, including members of 'prestigious' English families. ${ }^{22}$ From London, the Mantua, operated by the Peninsular and Oriental Steam Navigation Company (P\&O), called at Arosa Bay on 9 June 1911, according to an itinerary that also featured two stopovers in the Canary Islands. ${ }^{23}$ During their short stay in Galicia, 'most' of the 250 'distinguished' tourists travelling on the English ship visited the newly established and reportedly 'charming' pleasure resort of La Toja, while the others went to Santiago aboard a special train, where they were received by a local council committee and the municipal band. ${ }^{24}$ With respect to the Mediterranean coast of Spain, the highest traffic is seen in Malaga, Palma de Mallorca and, to a lesser extent, Barcelona. The arrival of American cruise ships was almost exclusively concentrated in Cadiz. Throughout this first stage, Cadiz was the entrepot to Andalusia for select cruises from New York. On 11 February 1905, for example, the 'magnificent' transatlantic liner Moltke, owned by the Hapag company, arrived. Some of the passengers also visited Seville on board a special train, making the most of the long stopover (40 hours). ${ }^{25}$ This detail should not be surprising, being one of the characteristic features of cruise activity at that time. While short port calls are the norm today

\footnotetext{
${ }^{20}$ New York Daily Tribune, 15 January 1905, 4.

${ }^{21}$ Gaetano Cerchiello, La evolución de los cruceros maritimos en España. Desde sus comienzos hasta la actualidad (1848-2016), (Valencia: Universidad de Valencia, 2017), 49-50.

${ }^{22}$ El Noroeste, 3 June 1904, 1.

${ }^{23}$ The Tatler, 12 April 1911, no 511, 8; La Gaceta de Tenerife, 1 June 1911, 2.

${ }^{24}$ El eco de Santiago, 9 June 1911, 2. On the British tourism in Galicia in the years before the First World War see Kirsty Hooper, Mondariz-Vigo-Santiago. A brief history of Galicia's Edwardian tourist boom, (Mondariz: Fundación Mondariz Balneario, 2013) and Kirsty Hooper, 'Spas, steamships and sardines: Edwardian package tourism and the marketing of Galician regionalism', Journal of Tourism History 4, no 2 (2012): 205-224.

${ }^{25}$ El Guadalete, 11 February 1905, 2.
} 
(cruise ships generally stop for only a few hours), the itineraries at that time included very long stops in many transit ports, some lasting for several days. The programme for the above-mentioned cruise included a stopover of 89 hours in Istanbul and another of 104 hours in Naples. ${ }^{26}$ Until very recently, land trips constituted the true essence of cruise tourism, with ships having the function of merely transporting passengers between stops.

Although things changed over time, the number of port calls on Spanish soil was initially very low. An analysis of itineraries reveals that leisure cruise ships, both those from Northern Europe and those from New York, avoided stopping at Spanish ports, preferring nearby sites such as Funchal, Lisbon, Tangiers, Gibraltar, Algiers, Marseille, Villefranche, and other such places on the French Riviera. This situation can be observed particularly during the early years of the twentieth century. The following examples reflect this reality. No Spanish port is present in the itinerary of the Mediterranean cruise undertaken by the Celtic between February and April 1902, carrying 800 'wealthy' North American citizens. ${ }^{27}$ The trip was arranged by the Frank C. Clark travel agency, one of the first intermediate companies that carried out the organisational tasks involved in producing cruises for the North American market, together with American Express, Raymond \& Whitcomb, Frank Tourist and Thomas Cook $\&$ Son. ${ }^{28}$ In this case, the New York agency opted to call at Tangier, Algiers, Villefranche and Gibraltar. Two years later, the Prinzessin Victoria Luise only sailed along the Spanish coasts, according to the itinerary of a round-the-world cruise from Hamburg. The ship owned by Hapag stopped in the ports of Lisbon, Gibraltar and Villefranche. ${ }^{29}$ On 21 February 1912, the Vectis left Southampton to undertake a 30-day leisure cruise around the Mediterranean. The P\&O ship, one of the first vessels adapted exclusively for tourists, stopped in Lisbon, Gibraltar, Algiers and Marseille. ${ }^{30}$

The partial exclusion of Spanish ports from international cruise routes was due to a combination of two factors. The first is the image that Spain had abroad as a tourist destination. By 1900 its reputation had improved considerably. It is well known that Spain was largely absent from international tourism flows for a good part of the nineteenth century, especially as compared with France, Switzerland, and Italy. ${ }^{31}$ Structural issues, such as an entrenched shortage of hotel infrastructure and serious difficulties afflicting overland communications in many areas, were to blame. ${ }^{32}$ Furthermore, there was a general opinion that Spain was a nation permanently at war or

\footnotetext{
${ }^{26}$ New York Daily Tribune, 15 January 1905, 4.

${ }^{27}$ St. James's Gazette, 9 April 1902, 15; New York Daily Tribune, 12 January 1901, 4.

${ }^{28}$ Cerchiello, La evolución de los cruceros, 74.

${ }^{29}$ New York Daily Tribune, 10 April 1904, 15.

${ }^{30}$ The Western Gazette, 16 February 1912, 13; Sharon Poole and Andrew Sassoli Walker, P\&O Cruises. Celebrating 175 years of Heritage (Gloucestershire: Amberley, 2013), 26.

${ }^{31}$ Among others, Annunziata Berrino, Storia del turismo in Italia, (Bologna: Il Mulino, 2011).

${ }^{32}$ A brief summary of these reasons in Cerchiello and Vera-Rebollo, 'Steamboats and pleasure travels', 19-21.
} 
immersed in internal riots and uprisings. Travelling through the Spanish peninsula was generally perceived as unsafe. The country's image only began to change in the late nineteenth century. The proliferation of tourist guides and travel books on Spain is an indicator of increased interest. ${ }^{33}$ There is every suggestion that the influx of foreign visitors, particularly from Britain, significantly increased at the end of the century. ${ }^{34}$ After almost 60 years of publishing guidebooks, in 1897 Baedeker finally issued its first guide covering the Iberian Peninsula. An English language version of its Handbook for Travellers in Spain and Portugal appeared the following year. ${ }^{35}$ Several publications highlighted the political, economic and social improvements occurring after the midcentury. The 8th edition of the O'Shea's Guide to Spain and Portugal in 1889 emphasised that the country was 'rapidly changing with the spread of its railway system, its commercial development and the beneficent influence of a stable Government' after the Bourbon Restoration of 1874. According to this British travel guide, 'nearly every place or object of interest can now be visited with ease and in security and comfort' ${ }^{36}$ Other publications went even further and unhesitatingly confirmed that Spain had become a 'prosperous' modern society, far removed from the backward country of the nineteenth century. ${ }^{37}$

Nevertheless, opinions still varied; prejudices about Spain persisted. In 1913, the fourth edition of the Baedeker's guide to the Iberian Peninsula continued to express negative judgements concerning travel in Spain: accommodations, transportation, and so forth. 'Though an improvement may be noticed in recent years', the famous guidebook reported, the supply of 'really good' hotels in Spain was 'really' poor and 'hardly' existed, even in an important city such as Barcelona. ${ }^{38}$ In addition, the service in hotels was 'generally very slack', while cafés were 'often very deficient in comfort and cleanliness'. ${ }^{39}$ The climatic 'advantages' offered by places on the Mediterranean coast, such as Alicante and Malaga, were 'largely counterbalanced by their dirt, dust and general lack of comforts'. ${ }^{40}$ Tourists were also recommended to take great care when going on trips outside of towns, particularly in the south of Spain as there were still cases of 'highway robbery

\footnotetext{
${ }^{33}$ Rafael Vallejo-Pousada, Elvira Lindoso-Tato and Margarita Vilar-Rodríguez, 'Los orígenes históricos del turista y del turismo en España: la demanda turística en el siglo XIX', Investigaciones de Historia Económica - Economic History Research (2018), DOI: 10.1016/j.ihe.2018.03.001 (accessed 3 December 2018).

${ }^{34}$ Kirsty Hooper, 'La imagen de España en el primer tercio del siglo XX a través de la literatura de viajes británica', in Vallejo-Pousada and Larrinaga (dirs.), Los orígenes del turismo moderno en España. El nacimiento de un país turístico, 1900-1939, (Madrid: Sílex, 2019), 599-634.

35 Ibid., 599-600.

${ }^{36}$ John Lomas (ed.), O'Shea's Guide to Spain and Portugal, 8th edition, (Edinburgh: Adam and Charles Black, 1889), preface, already cited by Vallejo-Pousada et al., 'Los orígenes históricos', 4.

${ }^{37}$ Hooper, 'La imagen de España', 609.

${ }^{38}$ Karl Baedeker (ed.), Handbook for Travellers in Spain and Portugal, 4th edition, (Leipsic: Baedeker, 1913), vi, xxv.

${ }^{39}$ Ibid., xxv, xxviii.

40 Ibid., Xxxviii.
} 
(bandolerismo)'.${ }^{41}$ Meanwhile, the train continued to be the only recommended means of transport, despite being 'very slow' and 'inferior' to those of other countries; the use of diligences was not to be recommended 'even to those travellers who wish[ed] to study economy'. ${ }^{42}$

Whether they were true or not, it is logical to assume that such assessments continued to encourage negative impressions of a country that still did not offer the most ideal conditions for foreign visitors. In this respect, we might add that promotion of Spain abroad as a tourist destination at the beginning of the twentieth century was practically non-existent, except for a few isolated efforts made by the first Sindicatos de Iniciativa y Turismo, private local organisations emerging in different parts of Spain in order to promote arrivals by (foreign) tourists. ${ }^{43}$

With respect to leisure cruises, additional issues relating to maritime transport must be noted. Spanish port infrastructure, in general, was inadequate for supporting this type of traffic. The size and characteristic of the quays, not to mention inadequate harbour depths, among other inconveniences, did not allow the mooring of large foreign transatlantic ships in many ports. They had to anchor far from shore, creating added challenges for excursionists. The arrival of the Moltke in Cadiz in February 1905 illustrates these weaknesses. The operation to disembark the 310 North American passengers was staggered and required a steamboat. ${ }^{44}$ Other major obstacles to capturing cruise traffic encompassed the slowness of customs formalities in several ports, including Barcelona, and, above all, high port dues. ${ }^{45}$ At the beginning of the century, taxes applied in Spanish ports were 'more expensive' than in other countries in the Mediterranean area and were only comparable to Italian ports. ${ }^{46}$ This situation worsened with enforcement of the so-called Impuesto de Transporte in March 1900. The new law imposed payment of a tariff, variable depending on the class of accommodation and the navigation route, both on those passengers who were starting or ending a trip and to those who were disembarking during a stopover operation. ${ }^{47}$ The amounts were not small. For example, first-class passengers from North America who wished

\footnotetext{
${ }^{41}$ Ibid., xxx. On this regard Eugenia Afinoguénova and Eduardo Rodríguez Merchán, 'Picturesque violence: tourism, the film industry, and the heritagisation of 'bandoleros' in Spain, 1905-1936', Journal of Tourism History 6, no. 1 (2014): 38-56.

42 Baedeker, Handbook for Travellers in Spain, xviii, xxii.

${ }^{43}$ Marta Luque Aranda and Carmelo Pellejero Martínez, 'La promoción turística privada en la España del primer tercio del siglo XX: los Sindicatos de Iniciativa y Turismo', Investigaciones de Historia Económica - Economic History Research 15, no 1 (2019), 38-46; Rosa Cal and Beatriz Correyero, Turismo, la mayor propaganda de Estado. España: desde sus inicios hasta 1951 (Madrid: Vision Net, 2008), 51-57; Juan C. González, 'Los orígenes de la industria española de los forasteros', Cuadernos de Historia Contemporánea 37, no 1 (2015): 145-175.

${ }^{44}$ El Guadalete, 11 February 1905, 2.

${ }^{45}$ Albert Blasco, 'Barcelona Atracción (1910-1936). Una revista de la Sociedad de Atracción de Forasteros' (Ph.D. diss, University Pompeu Fabra, 2005), 413.

${ }^{46}$ Museo Marítimo de Barcelona, Fondo Trasatlántica, box 103, Estudio comparativo de los derechos de puerto en España y en el extranjero (1903).

${ }^{47}$ Gaceta de Madrid, March 25, 1900, nº 84, 1053-1055.
} 
to disembark, even for a few hours, had to pay 25 pesetas (about $\$ 3.5$ in that year). ${ }^{48}$ Local tourism organisations strongly criticised the application of this measure and made several appeals to the Spanish government for the modification of port dues 'in such a way so as to favour the interests of tourism'. ${ }^{49}$

In light of all of these structural obstacles and difficulties, it was logical that shipping companies and foreign travel agencies opted to call at other foreign ports. The clearest case refers to Gibraltar, although the main attraction of this stopover was, in fact, the train excursion to Granada. An analysis of the advertising material leaves no doubt about this. The port call in Gibraltar was promoted as the 'opportunity' to see Spain with a visit to the city of Granada and its surrounding areas. $^{50}$

\section{The leisure cruise business in the 1920s: growth and strategic change}

By the mid-1920s, the situation for transatlantic passenger lines was very different from what existed at the beginning of the century. Despite large losses suffered during the First World War, the global merchant shipping industry quickly recovered to 1914 levels. By around 1923, merchant fleets had recovered more than a third of their pre-war capacity. ${ }^{51}$ Shipyards worked at full speed during the war and this certainly continued during the post-war years. The 'most powerful' production volumes were recorded between 1921 and 1923, with an average of more than seven and a half million gross tonnes (hereafter GT) which generated the launch of many passenger ships and other vessels. ${ }^{52}$ Cunard is one of the most illustrative examples. Between 1919 and 1925, the British shipping company incorporated 13 newly-built transatlantic vessels into its fleet, with a total of 212 thousand GT. To this figure we should add the 52 thousand tonnes of the Berengaria (ex Imperator), one of the many maritime transport units confiscated from the Germans. ${ }^{53}$

The commissioning of new transatlantic vessels was strongly stimulated by the revival of passenger demand. During the first years after the war, international migration increased at a sustained rate. More than 415 thousand Italians migrated to a transoceanic country in 1920: a figure very similar to those recorded in the early years of the century (Figure 1). European emigration to the United States exhibited the same upward trend (Figure 2). Throughout 1921, more than 650

\footnotetext{
${ }^{48}$ The exchange rate is based on Pablo M. Aceña and María A. Pons, 'Sistema monetario y financiero', in Estadísticas Históricas de España, Siglos XIX y XX, eds. Albert. Carreras and Xavier Tafunell (Bilbao: Fundación BBVA, 2005), 703-4.

${ }^{49}$ La Vanguardia, 8 November 1923.

${ }^{50}$ Among others, Thos. Cook \& Son (1902); New York Daily Tribune, 11 January 1903, 10.

${ }^{51}$ Instituto Nacional de Estadística, L'Italia in 150 anni.

52 Vida Marítima magazine 739, 30 May 1923, 147-148; Vida Marítima magazine 973, 15 May 1933, 161-162.

${ }^{53}$ Francis E. Hyde, Cunard and the North Atlantic, 1840-1973: A History of Shipping and Financial Management, (London: Macmillan, 1975), 334-335; Lloyd's Register of Shipping, 1925.
} 
thousand European migrants arrived at American ports. This was a considerable increase with respect to the previous year $(+165 \%)$. The business of the transatlantic shipping lines, therefore, seemed to be heading towards a full and total recovery. It looked as though the 'feverish' activity of the pre-war years would be the most predictable scenario. However, this was not the case. Longdistance passenger demand fell drastically, giving rise to a long crisis in shipping line services. The decision by the United States government to end the 'open ports' policy was the main cause. The severe cutbacks and the entry quotas particularly affected European emigration. In 1925, it had reduced to less than one quarter, stabilising at this level until the end of the decade (Figure 4).

Figure 4. Evolution of the entrance of European immigrants into the United States. Thousands of people (1899-1930)*

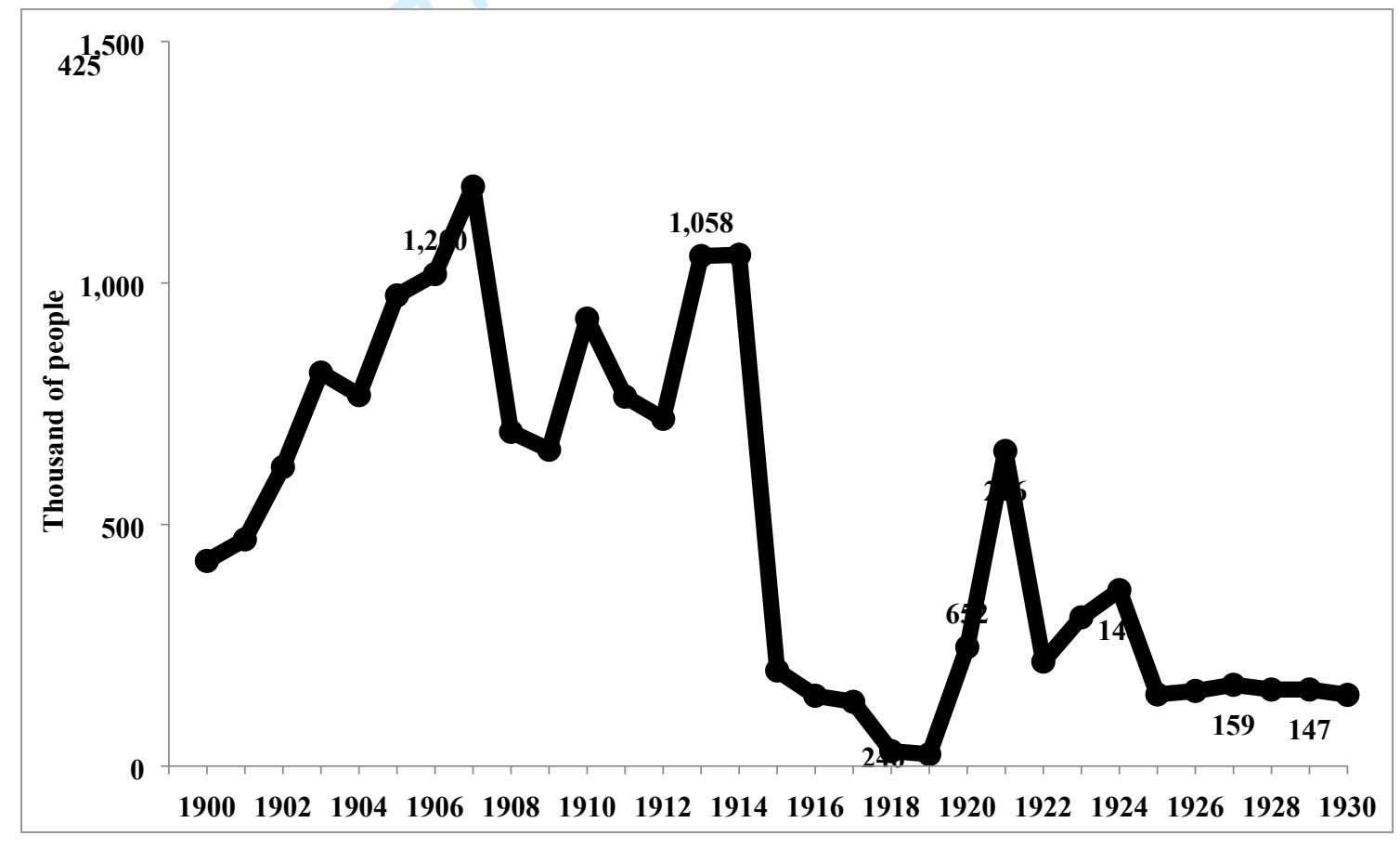

* The above data refers to US fiscal years (1 July-30 June) Source: U.S. Department of Labor, Annual Report of the Commissioner General of Immigration 1911-1914, 1921, 1930

'One of the outstanding facts of the modern world since 1920', as Frederick W. Ogilvie wrote at that time, was 'the drying-up of the great stream of transoceanic migration which had flowed, dramatically and effectively, from Europe to the New World for a hundred years'. ${ }^{4}$ The restrictive measures approved in the United States, together with other factors emerging during the 1920s, such as the gradual improvement of the European economies with the consequent reduction in unemployment rates (e.g. The United Kingdom) or the change in the migration policies of some countries (e.g. Italy), represented a hard blow for transatlantic shipping companies. ${ }^{55}$ The sector

\footnotetext{
${ }^{54}$ Frederick Wolff Ogilvie, The Tourist Movement. An Economic Study, (London: P.S. King \& Son Ltd, 1933), 37.

${ }^{55}$ Aldcroft (2003).
} 
began to exhibit a growing imbalance due to a high excess capacity with respect to traffic demands. Between 1920 and 1925, for example, the Spanish Compañia Trasatlántica saw how the emigrant passengers of its seven line services dropped by more than $45 \%$, while its transport capacity, in GT terms, increased by more than $21 \%$. During the following five-year period, the migrants on board the Spanish company's ships fell by a further $32 \% .{ }^{56}$

In order to mitigate this situation, shipping companies changed their strategy. From the middle of the decade, the supply of leisure cruises increased exponentially relative to the decrease in the number and frequency of line services. ${ }^{57}$ According to an article published in Revista de Viajes, a magazine issued by Thomas Cook and Son in mid 1927: 'Although recreational cruises are, so to speak, in the period of their infancy, there is no doubt that these are children who are growing very phenomenally quickly'. ${ }^{58}$ The rareness and seasonality that had characterised tourism cruise traffic until then gave way to huge flows spread over all twelve months of the year. The Neptunia, operated by the Italian company Sitmar, undertook 10 cruises in 1926, including three trips around Northern Europe from its base in Hamburg. According to advertisements and press chronicles, operations began on 21 January and finished on 27th October, accumulating approximately 220 days of tourism navigation. ${ }^{59}$ Between January and May 1926, the Royal Mail Steam Packet organised seven long Mediterranean cruises starting at Southampton. ${ }^{60}$ Three were aboard the Orbita and the rest on the Arcadian. During the summer season, the latter vessel was positioned in the ports of Leith and Immingham to offer several cruises de luxe around Norway and the Baltic Sea. ${ }^{61}$ Between May and September 1926, the Ranchi, owned by P\&O, organised six cruises of between 16 and 30 days departing from London, accumulating a total of 134 days of navigation. ${ }^{62}$ One of its most attractive projects was the trip around the Atlantic islands of the Azores, Madeira and the Canary Islands. When passing through Tenerife, the 'magnificent' transatlantic English ship carried a little less than 500 passengers, the 'majority' of whom joined the excursion to the north of the island. ${ }^{63}$ Cunard also illustrates the strategic change adopted by the transatlantic shipping companies. Several of its vessels were retired from the North Atlantic route, either partially or permanently, and began operating in the tourism market. Their presence in the Mediterranean was increasingly regular. In 1926, for example, the Scythia, Samaria, Mauretania, Franconia, Laconia

\footnotetext{
56 Compañía Trasatlántica, Annual Report, 1925, 1930; Compañía Trasatlántica, Información de la Compañia Trasatlántica ante el proyecto de ley anulando su contrato con el estado, (Madrid: Gráfica Reunidas, 1934$), 34$.

${ }^{57}$ Williams, 'Humankind and the Sea', 7; Cartwright and Clive Harvey, 'Cruise Britannia', 19.

${ }^{58}$ Revista de Viajes magazine 14, April-June 1927, 14 (author's translation).

59 The estimate is based on: La Stampa, 2 March 1926; La Stampa, 10 June 1926; La Stampa, 8 September 1926; La Vanguardia, 6 January 1926; La Vanguardia, 5 March 1926; La Vanguardia, 21 May 1926.

${ }^{60}$ The Western Morning News and Mercury, 16 October 1925, 6.

${ }^{61}$ William H. Miller, Royal Mail Liners 1925-1971, (Gloucestershire: Amberley, 2017).

${ }^{62}$ Aberdeen Press and Journal, 15 April 1926, 5.

${ }^{63}$ La Prensa, 15 June 1926, 1.
} 
and Carinthia could all be seen in the Mediterranean. ${ }^{64}$ The latter berthed in the port of Cadiz on 13 April with 350 passengers. ${ }^{65}$

Following the same modus operandi as the line services, their ships called at Spanish ports to collect more passengers. Through their agents and local offices, many foreign shipping companies began to target Spanish clientele, offering them the opportunity to enjoy a new type of product. The projects of the afore-mentioned Sitmar for example, were preceded by a huge advertising campaign in the Spanish press. ${ }^{66}$ The Italian company provided a cruise service in Spanish ports which customers could reserve in advance at its agents' offices. ${ }^{67}$ In this way, it designed a tailor-made cruise for Spanish passengers. Travel agencies which organised cruises also adopted this strategy in an effort to expand their geographic reach. American Express, for example, began to market their products in Spain through the press and its local branch offices. In February 1923, the American company offered the opportunity to enjoy a long cruise around the Mediterranean on board the Mauretania which would also pick up passengers in the port of Cadiz. The transatlantic liner began its crossing in New York with 550 tourists on board. Due to its enormous size - 32,000 GT, $232 \mathrm{~m}$ in length and more than $10 \mathrm{~m}$ in depth - the Cunard vessel had to drop anchor 'some way' from the roadstead of the port of Cadiz. Added to this, appalling weather conditions then delayed the embarking and disembarking operations of the three steamboats used for this service. As a consequence, excursions organised to Seville and Granada had to be cancelled. ${ }^{68}$

\section{The boom of the 1930s: a precursor of modern popular cruises}

The downturn suffered by the maritime transport sector during the years following the 1929 economic crisis, which led to a substantial amount of inactive tonnage, unleashed a subsequent increase in the supply of tourism cruises. ${ }^{69}$ Advertisements filled the pages of newspapers and blanketed the walls of shipping company offices. ${ }^{70}$ For many companies, this 'new form' of traffic became their main line of business. The number of transatlantic liners engaged in the tourism market increased 'extraordinarily' and 'universally'. It is estimated that approximately 175 thousand British people went on a cruise in 1931. More than 200 cruises were organised in 1934, departing from England via 46 liners, the equivalent of more than 750 thousand GT. ${ }^{71}$

\footnotetext{
${ }^{64}$ Belfast New Letter, 4 September 1925, 6; The Sphere, 21 November 1925, 20.

${ }^{65}$ El Noticiero Gaditano, 13 April 1926, 1.

${ }^{66}$ La Vanguardia, 21 May 1926.

${ }^{67}$ Navegación, 4 January 1921.

${ }^{68}$ Diario de Cádiz, 17 February 1923.

${ }^{69}$ Williams, 'Humankind and the Sea', 7.

${ }^{70}$ Eloy Sánchez, Mi crucero a Spitzberg, (Cáceres: Extremadura Edición, 1935), 7.

${ }^{71}$ Cartwright and Clive Harvey, 'Cruise Britannia', 16; Vida Maritima magazine 996-997, 28 February 1934, 31-34.
} 
The 'fierce' competition caused a 'considerable' fall in prices. ${ }^{72}$ Several shipping companies reorganised passenger distribution, increasing the range of classes available aboard leisure cruises. In this way, companies adopted the traditional separation which characterised line voyages for the tourist trade. There was logic to this measure. After all, the transatlantic liners had been built to transport many different types of passenger, particularly from the lower classes. Cruises were diversifying in all aspects: duration, destination, time of year and finally, also in the socio-economic aspects of the clientele. This latter reality required the companies to target a much more heterogeneous market. The traditional elite clientele was not sufficient to cover the needs of the new form of traffic. For this reason, it was the shorter length cruises that grew the most. In the spring and summer of 1933, for example, Canadian Pacific organised no less than 32 popular cruises of between six and fourteen days including a special project designed for British students calling at Madeira, Casablanca and Gibraltar. ${ }^{73}$

The best example of this change is reflected in Figure 5 which shows an advertisement for P\&O cruises sailing during the spring-summer season of 1935. The British company continued to offer exclusive high-end voyages on board the Viceroy of India, a modern transatlantic liner only available to first class customers. At the same time, on its twin vessels, Strathnaver and Strathaird, the company opted to provide tourist class offerings, alongside more expensive first class births. Finally, it also targeted only tourist class passengers with 11 cruises on board the Mongolia and the Moldavia, two more modest transatlantic liners. Thus, when the Viceroy of India berthed in the port of Tenerife on 11 January 1935 as part of a cruise departing from Southampton, the transatlantic liner of almost 20,000 GT was undertaking an elite expedition for 'just' 268 passengers. ${ }^{74}$ By contrast, the Moldavia was carrying 614 passengers when it passed through La Coruña on 1 May 1935, even though this liner had a much smaller capacity (16,500 GT). ${ }^{75}$ Meanwhile, the Strathaird and Strathnaver each carried more than a thousand passengers. The former called at La Coruña at the end of May 1935 with 1007 passengers. ${ }^{76}$ The latter arrived in Cadiz on 25 August of the same year with 1052 clients on board..$^{77}$

\footnotetext{
${ }^{72}$ Ibid.

${ }^{73}$ Belfast News Letter, 4 April 1933, 1; Daily Herald, 5 April 1933, 10.

${ }^{74}$ La Prensa, 12 January 1935, 1-2.

${ }^{75}$ Archivo General de la Administración, Fondo Cultura [hereafter, AGA, Cultura], box 11996.

${ }^{76}$ AGA, Cultura, box 11996.

77 AGA, Cultura, box 11996.
} 
Figure 5. Advertisement for cruises of the P\&O company in different classes (1935)

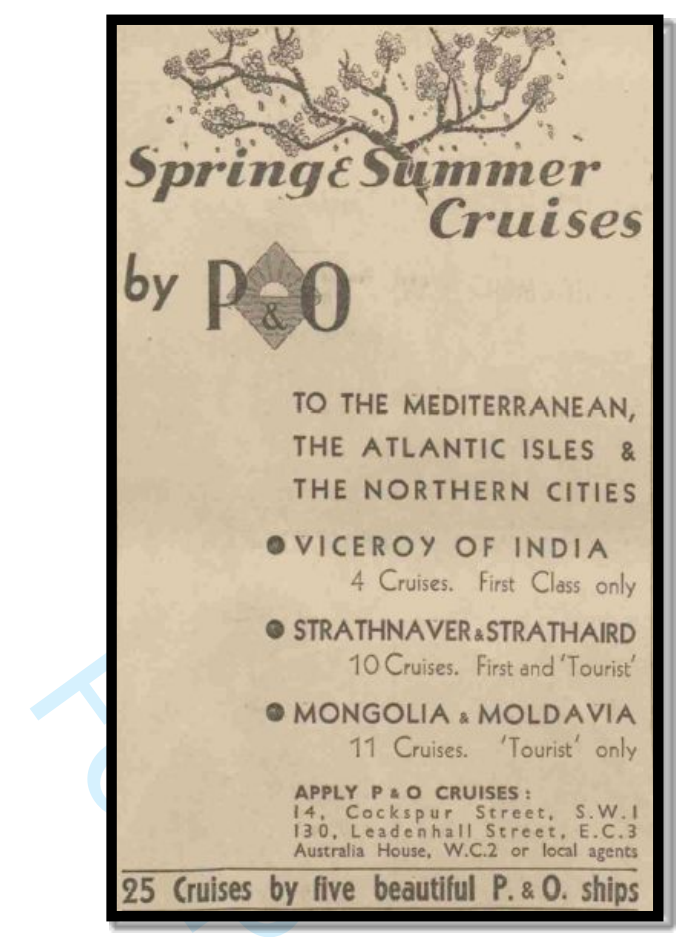

Source: The Western Times, 15 February 1935, 6.

Prices reflect the variety of cruises offered by $\mathrm{P} \& \mathrm{O}$. The most economical rate for the 14-day cruise on the Viceroy of India was a little more than $£ 25$ per person (24 guineas), which was more than double the price of a trip with a similar itinerary and duration on board the Moldavia (11 guineas).$^{78}$ In the British market prices decreased considerably. Going on a cruise aboard an English vessel was, in fact, much cheaper than doing so on a Spanish ship. In the mid 1930s a pleasure cruise of just 7 days aboard the Juan Sebastián Elcano, operated by Compañía Trasatlántica, cost no less than 750 pesetas (about £18). ${ }^{79}$

The range of cruises that passed through Spain in the mid 1930s was extensive and varied. At one end of the scale were elite trips aboard liners such as the Duchess of Richmond. When it passed by the island of Tenerife on 30 January 1935, the Duke and Duchess of Kent were on board the Canadian Pacific transatlantic liner together with a further 383 'distinguished' passengers. ${ }^{80}$ Cruises aboard small and 'luxurious' ships such as the Meteor and Stella Polaris should also be included in this category. ${ }^{81}$ The latter made port calls at the beginning of October 1935 at Tenerife and Cadiz with 171 passengers on board. ${ }^{82}$ At the other extreme were the contingents who travelled on the German vessel Monte Rosa or the English ships Montclare and Montrose. These three vessels

\footnotetext{
${ }^{78}$ Western Daily Press, 18 December 1934, 8; Oasis, 1 February 1935, n 4, 136; La Vanguardia, 23 February $1935,9$.

${ }^{79}$ Oasis magazine 3, 1 January 1935, 66; the exchange rate used is based on Aceña and Pons, 'Sistema monetario'.

${ }^{80}$ La Prensa, 31 January 1935, 1.

${ }^{81}$ Philip S. Dawson, Cruise Ships. An evolution in design, (London: Conway Maritime Press, 2000), 21-22.

${ }^{82}$ AGA, Cultura, box 11996.
} 
accounted for almost 2,135 passengers in the three port calls that they made to Barcelona in 1935. ${ }^{83}$ This mass participation should not be surprising. Choosing tourist accommodation, a two-week Mediterranean leisure cruise departing from Liverpool, Southampton or another English port could cost less than one pound per day per person. It was not in vain that Canadian Pacific promoted these offerings as 'Popular Priced Cruises'. 84

Clearly, many of the trips organised during the 1930s were not elite cruises. Tourists of different socio-economic backgrounds travelled on these liners. Madrid and Tenerife newspapers reported that the 'fashion' of cruises spread because foreign companies needed to offer accessible rates for 'all', particularly the middle classes. ${ }^{85}$ It was clear that the clientele of many cruises, particularly those departing from England, spent much less on land during stopovers than in the past. The tourist office in the Port of Barcelona indicated the 'new' presence of members of the working classes from Liverpool, Manchester and other English cities. ${ }^{86}$ An article published in February 1933 by the Catalan daily newspaper, La Vanguardia, clearly reflects the change in maritime passenger transportation:

The shipping companies, which have suffered most directly the consequences of the severe crisis in which the world is immersed, have chosen between mooring their vessels due to a lack of demand or mitigating their losses by using them for tourist trips, the organisation of which has been increasing for some time (...). Therefore, the flood of tourists enter Spain not because they are attracted by the beauties of our soil, with all its variety and evocative charm, but rather as a consequence of an enormously practical circumstance which will disappear as soon as the context that fosters it ceases to exist (...). ${ }^{87}$

On a national level, cruise traffic benefited from the greater involvement of the State in tourism. As is well known, this began in April 1928 with the creation of the Patronato Nacional del Turismo (National Tourist Board). ${ }^{88}$ This body undertook operation of the first official tourist offices in the principal foreign tourist issuing markets and implemented a broad and costly propaganda campaign 'in order to promote tourism in Spain'. ${ }^{89}$ Between 1928 and 1930, the PNT invested about $4,350,000$ pesetas (more than $£ 85,000$ ) in tourism publications and propaganda, more than $20 \%$ of

\footnotetext{
${ }^{83}$ Cerchiello, La evolución de los cruceros, 94.

${ }^{84}$ The Yorkshire Post, 25 July 1935, 1; The Scotsman, 1 March 1935, 1.

${ }^{85}$ La Libertad, 7 July 1933, 11. La Prensa, 28 July 1933; La Prensa, 1 October 1935.

${ }^{86}$ La Vanguardia, 23 February 1935, 9-10.

87 'El turismo marítimo', La Vanguardia, 16 February 1933, 19 (author's translation).

${ }^{88}$ Rafael Esteve and Rafael Fuentes, Economía, historia e instituciones del turismo en España, (Madrid: Pirámide, 2000), 29; Carmelo Pellejero, 'La política turística en España: una perspectiva histórica', Mediterráneo Económico 5, no 1 (2004): 269-270; Ana Moreno, 'Nacimiento y consolidación del turismo español. Su evolución en el siglo XX', Storia del Turismo Annale, no. 11 (2018): 75-90. Rafael Vallejo-Pousada, Margarita Vilar-Rodríguez and Elvira Lindoso-Tato, 'The tourism economy in Spain, 1900-1939: new sources, new methodologies and new results', Journal of Tourism History, 10, no 2 (2018): 105-129.

${ }^{89}$ Patronato Nacional del Turismo, Memoria de los trabajos realizados por el Patronato Nacional del Turismo desde julio de 1928 a 31 de diciembre de 1929, (Madrid: Gobierno de España, 1930), 39 (author's translation).
} 
the firm's total expenditures during these years. ${ }^{90}$ The purpose of the advertising campaign was 'principally' to promote foreign markets, but also to increase internal demand. A portion of the money was spent on foreign offices, such as one located in Piccadilly, a high-traffic London shopping street. This agency coordinated promotional actions in the United Kingdom which included the publication of many full-page advertisements in local newspapers and magazines. The example in Figure 6, which appeared in the early months of 1929, encouraged people not to miss the opportunity of visiting Spain, 'a land rich in beauty and history, with a climate for all seasons and a people who will make you welcome'.

But the 'arduous and difficult task of positioning Spain among the world's leading tourism nations' also required the implementation of a series of important legislative changes, particularly fiscal ones, with respect to port traffic. ${ }^{91}$ The most important measure was, undoubtedly, Royal Order 512, issued on 12 June 1929, which abolished the Impuesto de Transporte. The Ministry of Finance made this decision in order to 'facilitate' the arrival of 'tourist expeditions that were organised in certain foreign countries', and due to the 'considerable profits' that the 'movement of travellers generated for the country's economy. ${ }^{92}$ Therefore, all of the contingents of tourists embarking, disembarking or carrying out both operations in Spanish ports were exempt from paying this controversial tax. The Spanish government had granted requests made by both the shipping companies and local tourism promotion agencies. In March of the same year, it authorised the exemption of the payment of another tax (Impuesto de Transporte y Tonelaje) for all vessels that carried 'tourist expeditions for visiting Spanish ports and cities', with the only condition that they should not carry out 'any commercial operations'. ${ }^{93}$ Some months later, the Ministry of Finance decided to extend the exemption to tourism liners which embarked and disembarked passengers. ${ }^{94}$ The leaders of the PNT believed that the fiscal reductions had an 'extraordinary importance' for expanding tourism. The new measures enabled the 'principal' foreign shipping companies to 'make port calls at the Spanish ports and disembark their passengers, which had been previously impossible to verify'. ${ }^{95}$ From 1929, the first information offices were opened in the principal landing ports (Vigo, Málaga, Palma de Mallorca and Barcelona, among others). Their fundamental

\footnotetext{
${ }^{90}$ Patronato Nacional del Turismo, Memoria correspondiente a la liquidación, revisión y trasformación del Patronato Nacional del Turismo ordenada por el Gobierno provisional de la República en su decreto del 23 de abril de 1931, (Madrid: Gobierno de España, 1931), 119-158 (author's estimation).

${ }^{91}$ Patronato Nacional del Turismo, Memoria de los trabajos, 1 (author's translation).

${ }^{92}$ See the Spanish Official State Gazette, Gaceta de Madrid 177, 26 June 1929, 1779.

${ }^{93}$ Gaceta de Madrid 90, 31 March 1929, 2354-2355.

${ }_{94}^{4}$ Gaceta de Madrid 225, 13 August 1929, 1179; Ana Moreno, Historia del turismo en España en el siglo XX, (Madrid: Síntesis, 2007), 123.

95 Patronato Nacional del Turismo, Memoria de los trabajos, 123-124 (author's translation).
} 
mission was to 'regulate' and 'guide' the arrival of visitors to principal tourist attractions and to provide the first statistical data on incoming traffic. ${ }^{96}$

Figure 6. Advertisement for tourism in Spain in the British press (1929)

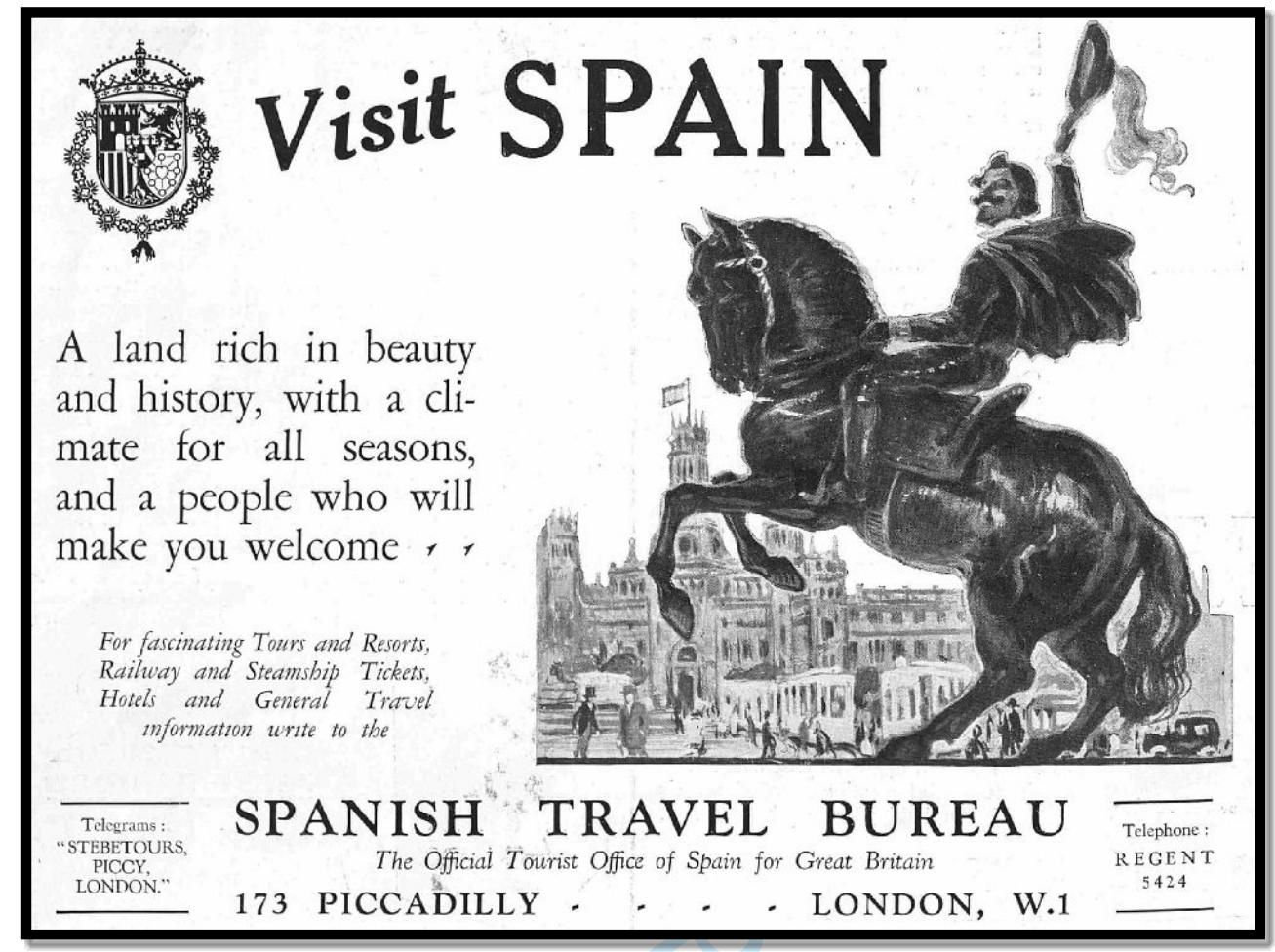

Source: The Graphic, 9 March 1929, 42.

In the following years, several Spanish sea ports were firmly established in international cruise itineraries. According to the information in Figure 7, Palma de Mallorca had become a compulsory port of call for foreign tourism ships and cruises generated the island's primary tourism clientele. The volume of annual arrivals exceeded 50 thousand passengers in 1934 and 1935, while overnight hotel stays did not surpass 40 thousand..$^{97}$ Before the Spanish Civil War (1936-1939), cruises also yielded a significant share of traffic in Barcelona, Tenerife, Cadiz and other ports, although with absolute values that were lower than the island of Mallorca (Figure 8).

\footnotetext{
${ }^{96}$ Ibid., 43-45.

${ }^{97}$ Cirer-Costa, 'Spain's new coastal destinations. 1883-1936: the mainstay of the development of tourism before the Second World War', Annals of Tourism Research 45, no 2 (2014): 24-25.
} 
Figure 7. The evolution of cruise traffic in Palma de Mallorca Number of calls and thousands of passengers arriving (1930-1935)

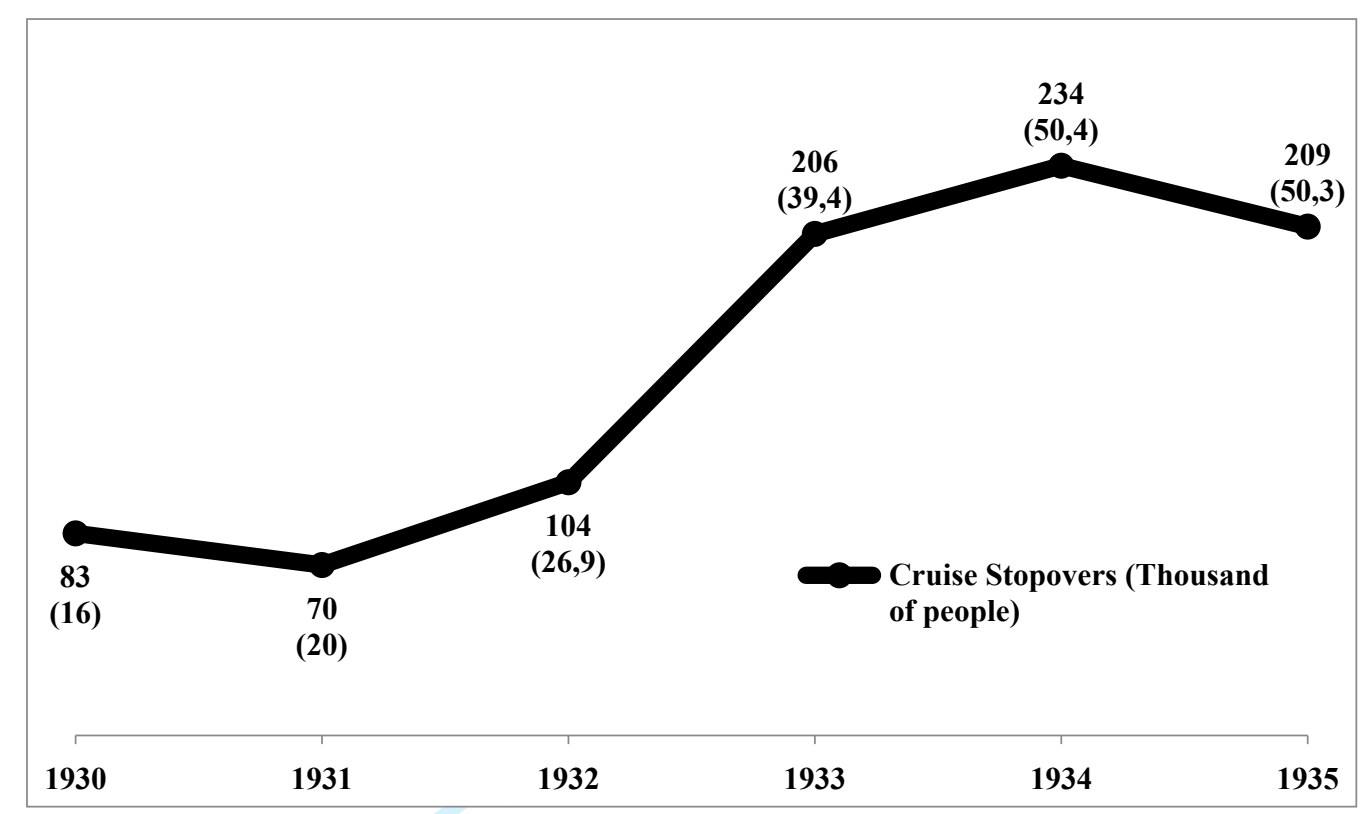

Source: Bartolomeu Barceló, 'El turismo en Mallorca en la época de 1925-1936', Boletín de la Cámara de Comercio, Industria y Navegación de Mallorca 651-652, no 1 (1966): 47-61.

Figure 8. Stopovers of cruises in different Spanish ports (1935)

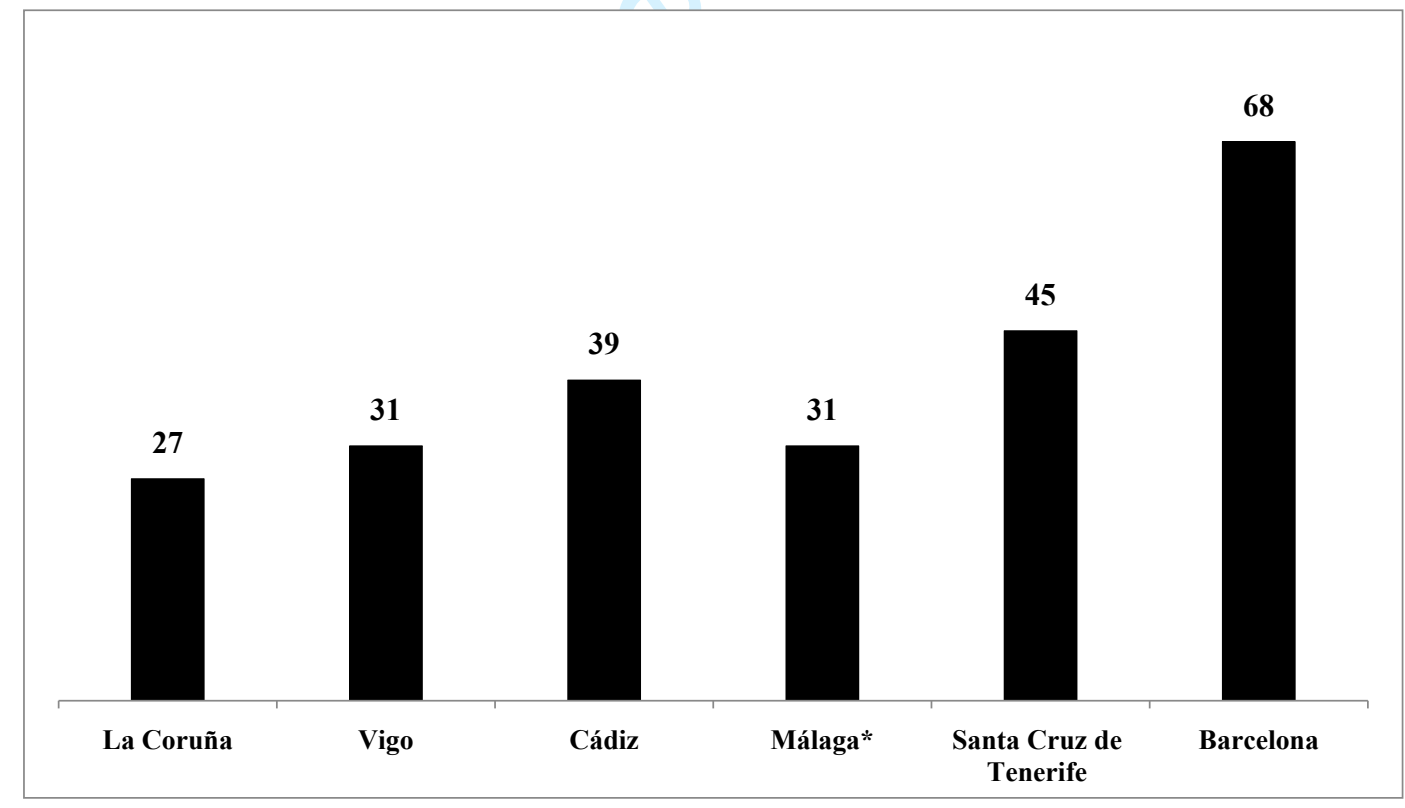

* The figure for Malaga does not include the port calls of the month of August. Source: Cerchiello, La evolución de los cruceros.

\section{Conclusions}

Cruise tourism experienced two very different stages of development during the first third of the last century. Before the First World War, it was a marginal activity and one that was restricted to an ultra-elite clientele. Ocean cruises were basically very long expeditions which were usually carried out during the low season for transatlantic line services. For this reason, the meagre traffic was 
concentrated in the winter season. The situation changed radically during the period between the two world wars, particularly in the 1930s, when the international supply of cruises increased exponentially. This new scenario, which was especially prominent in the United Kingdom, arose as a result of the crisis in the transoceanic passenger services. Shipping companies had to re-think their whole strategy due to the drastic reduction in emigration demand. Leisure cruises were adopted as a 'replacement market' and constituted the only alternative to the docking of transatlantic ships.

In the specific case of Spain, the meagre amount of inbound cruise traffic can also be attributed to internal challenges, such as high port dues, inadequate infrastructure at some ports and an unfavourable tourism image of the country abroad. These factors, which obstructed cruise stopovers in Spain in the early years of the twentieth century, gradually disappeared during the interwar years, mostly due to the state's involvement in tourism activity. The promotion of Spanish tourism abroad as well as the general reduction of port dues through certain government decrees, gave rise to the inclusion of several ports on international cruise itineraries.

The strong growth in cruise supply during the first half of the 1930s was accompanied by a marked deseasonalisation of the activity. Ocean cruises were organised throughout the twelve months of the year. An analysis of the port traffic of Tenerife, Cadiz and Barcelona corroborates the absence of seasonality of the new tourism trend in the mid-1930s (Figure 9). As regards the three Spanish ports, which are located in different geographical areas of the country (Canary Islands, Atlantic and Mediterranean mainland coast respectively), cruise traffic was even more intense during the summer season. The same sources also highlight the predominance of British cruises (figure 10). About 60 percent of the tourist expeditions had set sail from Southampton, Liverpool, London or other English ports. The remaining cruise liners departed from New York, Hamburg, Bremen, Genova, Marseille or Bordeaux, although there were also ships from Norway, Sweden, Belgium and even from ports of the former Yugoslavia. Based on this data, it is logical to presume that most cruisers who visited Spain in the mid-1930s were British. ${ }^{98}$

During the interwar years, ocean cruises also acquired a new social dimension. Though elites continued to take leisure cruises, such trips became an attractive holiday experience accessible to a much broader cross section of society. The overall fall in prices, thanks also to the reduction in the average length of trips, facilitated attracting a new type of client with less available time and money. This process is most evident in the British market on which we have particularly focused in this essay. P\&O, Royal Mail Steam Packet and Cunard, among other British companies, diversified their offerings by broadening the range of products: from the traditional luxury cruises for a limited

\footnotetext{
${ }^{98}$ Although most travellers embarked at the line's home port, it should be reiterated that several companies offered the opportunity to embark at other ports on the cruise itinerary. There is no evidence to indicate that all passengers had the same nationality as the respective port of departure.
} 
number of wealthy customers to popular cruises for the middle and working classes with a large number of passengers on board. Spanish port chronicles report on the presence of cruise liners of different types and capacities, some carrying more than 1,000 cruisers.

Figure 9. Distribution of the inbound cruise traffic in Tenerife, Cadiz and Barcelona according to the season. Percentages (1935)

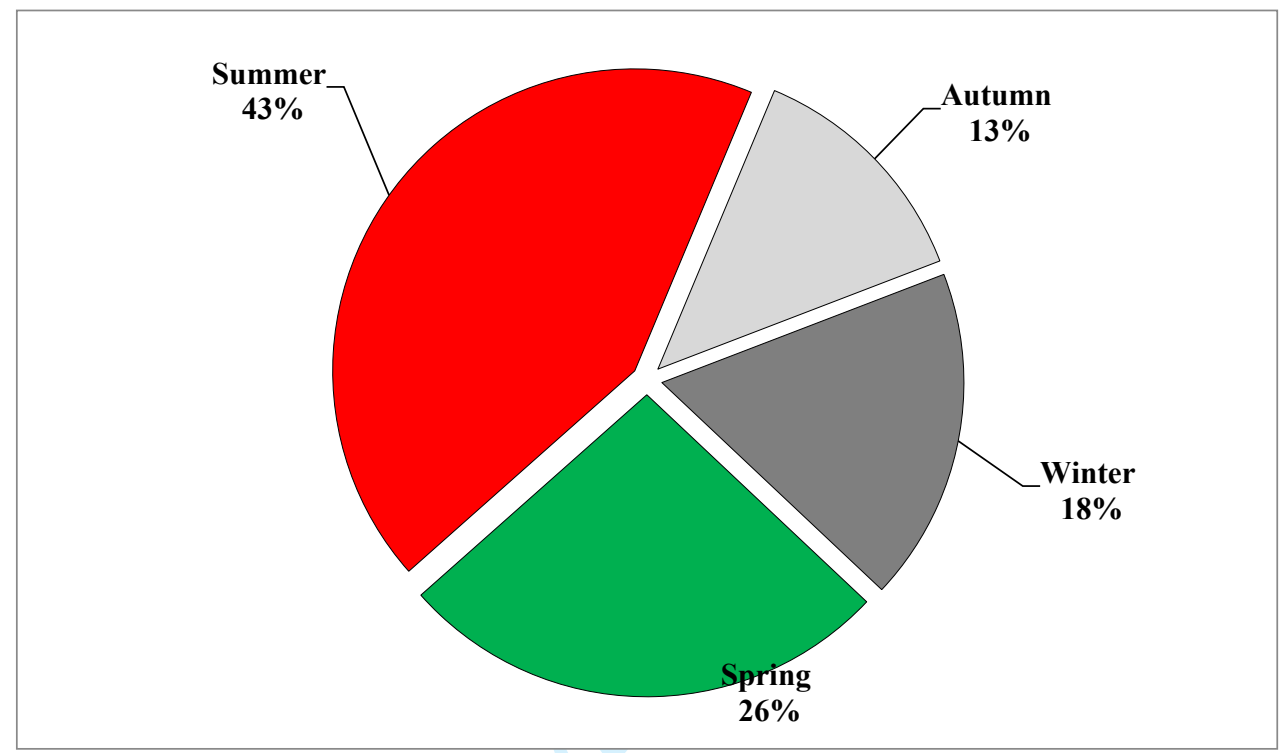

Source: respectively, La Prensa, daily editions 1935; AGA, Cultura, box 11996; La Vanguardia, daily editions 1935.

\section{Figure 10. Distribution of the inbound cruise traffic in Tenerife, Cadiz and Barcelona} according to the nationality of the port home. Percentages (1935)*

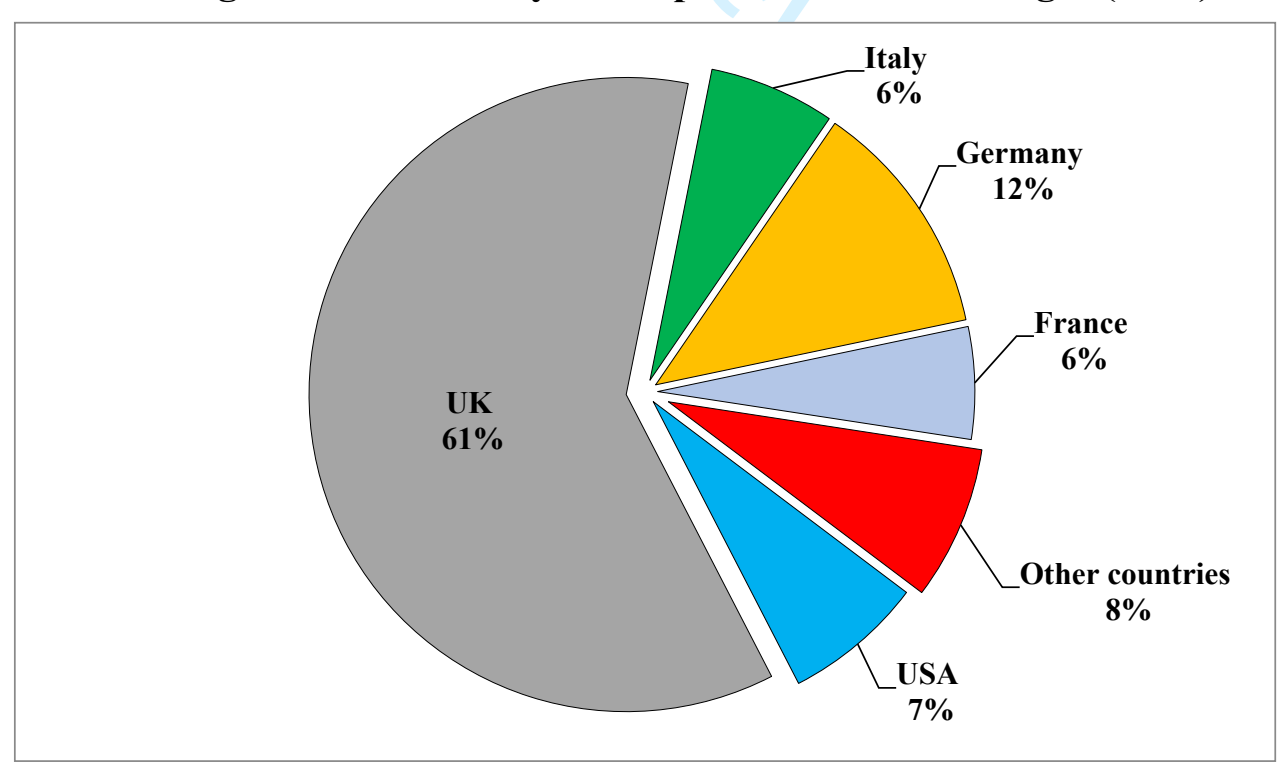

* This figure is based on 140 cruise port calls. The data does not include 12 calls at Barcelona whose origins are unknown.

Source: respectively, La Prensa, daily editions 1935; AGA, Cultura, box 11996; La Vanguardia, daily editions 1935. 
Finally, we should draw attention to the fact that the evolution of leisure cruises in the 1930s was very different from other types of tourism. While the tourism sector suffered the consequences of the 1929 economic crisis in general, leisure cruises experienced their first golden age, even becoming a popular product. Their 'autonomy' with respect to the tourism sector has a solid explanation. Although it was a recreational product, cruises were, above all, an activity of the shipping industry. Throughout this period, therefore, cruises evolved in line with the changes occurring in the maritime passenger transport sector, and more precisely in line with the cyclical variations of migration flows. Figure 11, referring to cruise traffic at the port of Barcelona between the years 1928 and 1935, may help to highlight this reality. It shows, on the one hand, an evolution in the number of port calls made by cruises; on the other hand, it illustrates the variation in the number of overnight stays enjoyed by foreign visitors in the hotels in the city of Barcelona. It is evident that there is no relationship between the two tourist flows, which, in fact, followed very different trends. The overnight stays in hotels increased significantly, coinciding with the organisation of the Universal Exhibition in Barcelona between May 1929 and July 1930 and subsequently dropped slightly in the following years. In contrast, the event evidently did not affect cruise traffic which, in fact, peaked several years later.

Figure 11. Evolution of inbound tourism in Barcelona, 1928-1935 Number of cruise stopovers and thousands of overnight stays of foreigners in hotels

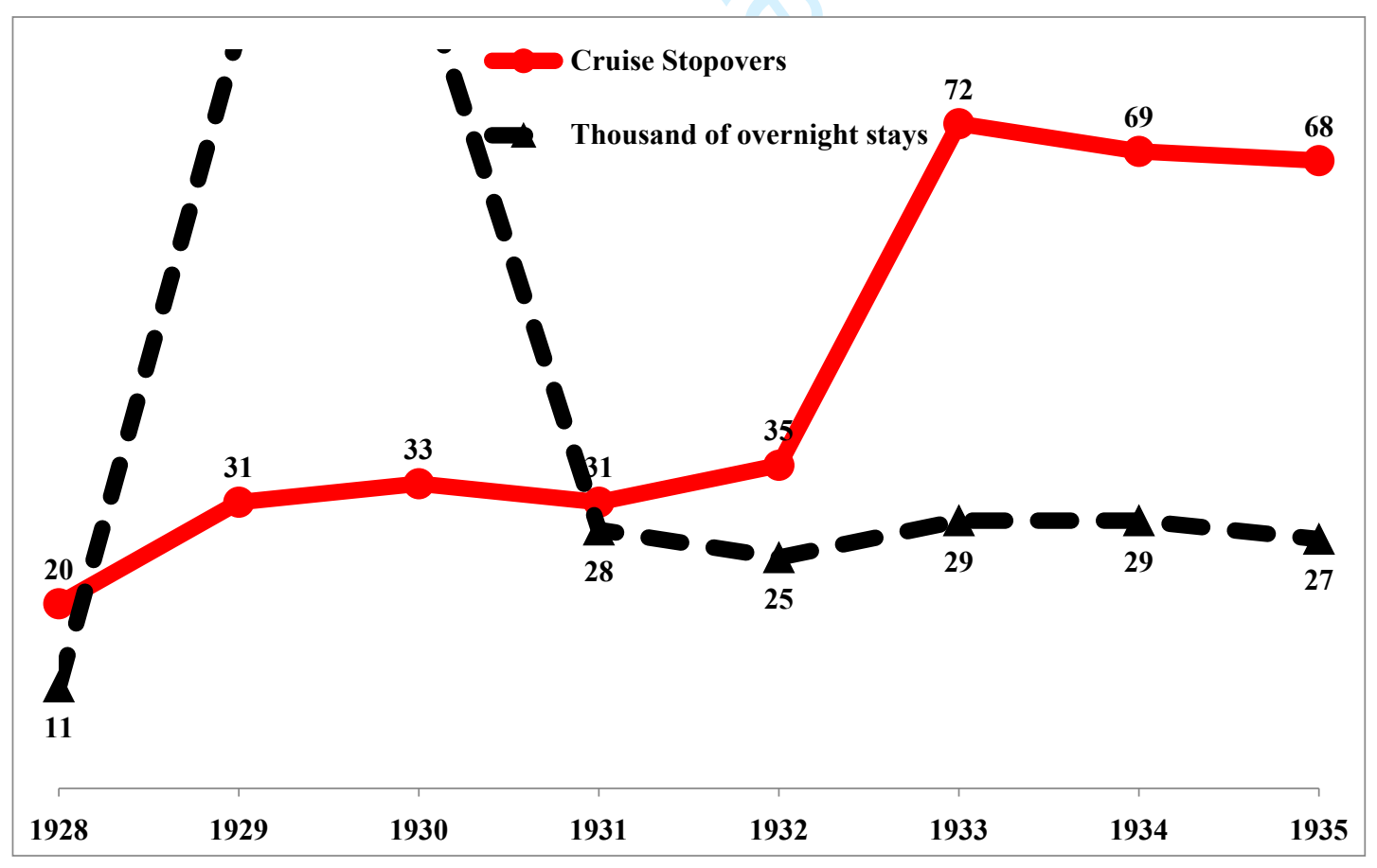

Source: Barcelona Atracción bimonthly editions (1929-1936)

The dependence of ocean cruises on migration flows continued until the 1960s. The irreversible crisis of transatlantic passenger shipping lines put an end to this 'strange' relationship, thereby 
giving life to the beginning of the modern cruise industry. Cruise activity was fully incorporated into the tourism sector within a context of widespread economic prosperity and the boom in mass tourism. However, we consider it important to stress that the background of contemporary popular cruises dates back to the early 1930s. In an age marked by a severe economic crisis, ocean cruises showed their full potential to become a successful mass product. 